\title{
Prospects of family farming: Ukrainian vs EU experience
}

\author{
Natalia Vasylieva \\ Department of Information Systems and Technologies, \\ Dnipro State Agrarian and Economic University, Dnipro, \\ Ukraine \\ Vasylieva.N.K@dsau.dp.ua (corresponding author) \\ Harvey James, Jr. \\ Division of Applied Social Sciences/Agricultural and Applied \\ Economics, CAFNR, University of Missouri, \\ Columbia, USA \\ HJames@missouri.edu
}

Abstract. Family farms are integral part of agricultural holdings and food production around the world. This research evaluates the current state and future prospects of family farming in Ukraine. Econometric methods allow us to evaluate absolute and relative dynamics in Ukrainian farming since 2002 and compare our findings with European indicators. The results reveal unstable positive progress in farming households' production of the prime national agricultural commodities, such as wheat, maize, sunflower, vegetables, potato, fruit and berries, broilers, eggs, and honey. However, Ukrainian family farms can successfully compete in supplying beef and milk at the domestic market. A ranking method helped us identify long-term prospects of Ukrainian commercial households among the EU family farms with a balance between crop and animal husbandry and distributions of utilized lands and livestock units. Social aspects of Ukrainian and EU family farming considered include age, gender, education levels, and the share of rural population. Statistical comparative analysis applied to family farming in Ukraine showed their poorer yields and effectiveness as compared to other agricultural enterprises in the country. Despite these challenges, agricultural contribution of commercial farming households allows us conclude that their development is necessary for providing food security in Ukraine and for improving welfare in its rural areas.

Keywords: Ukraine, family farming, commercial households, trends in agricultural production, the EU family farms, social characteristics, comparative effectiveness

JEL Classification: C1, O13, Q1

\footnotetext{
Received: January, 2020 1st Revision:

May, 2020

Accepted: September, 2020

DOI:

10.14254/2071 8330.2020/13-3/9
} 


\section{INTRODUCTION}

The United Nations declared 2014 to be the International Year of Family Farming. It highlighted a crucial link between the family as the basic social unit of society and the farm as a core economic unit in agriculture. Family farming is the cornerstone of rural development. It provides welfare in rural areas where agriculture is the original sector of self-employment. Family farming fosters local traditions, environmental biodiversity and national authenticity. Regardless of their size and capacity, many family farms are committed to semi-subsistence production as well as to fostering food security. The latter is especially important in view of the accelerated growth of the global population and the urgent search for means to supply food for over 9 billion people by 2050 (Knorr et al., 2018).

Such strong demand for food underpins the development of viable diversified food producers, ranging between large agricultural enterprises and small family farms (Sourisseau, 2015; Valin et al., 2018). The Food and Agriculture Organization reports that there are over 500 million family farms across the globe (Family Farming Knowledge Platform, 2019). This model of agricultural activity also prevails in Europe (Davidova \& Thompson, 2014). The EU statistics categorizes farms into groups based on the percent of family workers as follows: family workers are $100 \%$, above $50 \%$ (but not $100 \%$ ), below $50 \%$ (but not $0 \%$ ), and $0 \%$ of the regular farm labor force. By "family farm" we mean a farm where family workers provide at least a half of the regular labor force (Agriculture statistics - family farming in the EU, 2019).

Similar segments of Ukrainian agriculture are presented by households, private peasant holdings and individual farms. They appeared after the post-Soviet transformation of collective farms in 1995 and were supported by legislation in 2003. Presently, there are 4.5 million households in Ukraine, while the total population in Ukraine is 42.2 million people. Commercial farming households rely on family labor and sell without taxation up to $75 \%$ of their agricultural output. The average land size on a family farm in Ukraine is 1.2 ha but can go up to 3 ha if rented plots included. Nevertheless, their current output is $37.2 \%$ in Ukrainian crop production and 52.5\% in the national animal husbandry (State Statistics Service of Ukraine, 2019). Since Ukraine is seeking to improve its position within Europe and to adjust its economic and agricultural policy and practices as effectively as possible (Babenko et al., 2017), it is logical to find ways to enhance the positioning of Ukrainian family farming, the first logical step being its comparison with the EU family farming. The structural parts of such comparison should include:

- overviewing the current state of crop and animal production, utilized farmlands, and kept livestock units;

- matching demographic profiles of rural population engaged in family farming.

\section{LITERATURE REVIEW}

Recent scientific studies explored general opportunities and challenges for assisting family farming in the foreseeable future. For example, Gardner (2013) examined emerging technological, financial, environmental, and trade issues of providing food supply. Grafton et al. (2015) focused on optimal farm inputs and investments necessary to stay afloat among strong rivals. McKenzie and Williams (2015) considered ways and means of effective farming to provide affordable and available food before and beyond 2050 via sustainable intensification and advan management.

Bosc et al. (2018) conducted a multidimensional research of family farming in five continents. They explained the viability and resilience of family farms through permanent transformation, local knowledge, capability to seize new opportunities, and ability to cope with external obstacles. Lowder et al. (2016) reported that a majority of the 570 million farms around the world are family-run and small (less than 2 ha). The latter ones produce approximately $28 \%$ to $31 \%$ of crop husbandry and between $30 \%$ and $34 \%$ of 
total food supply (Ricciardi et al., 2018). This is another reason for studying carefully the phenomenon of small family farming. In this regard, Rapsomanikis (2015) revealed that family labor is a powerful driving force behind smallholders farming and demonstrated that there is an inverse relationship between farm size and productivity and that small family farms practice greater crops diversity, apply more inputs of seeds and fertilizers, and have less waste of yields than their larger counterparts.

Fienitz (2017) showed that small family farms in Europe acquired a minimal risk exposure and have an ability to survive despite a lack of bank loans and restricted land access. The development of smallscale family farms entails environmental benefits, such as improved landscape management, biodiversity enhancement, and water protection, as well as economic advantages in the form of job creation in rural regions and arranging short food supply chains for wider segments of urban customers. Davidova et al. (2013) found that three-quarters of all smallholdings in the EU belong to semi-subsistence farming. To a certain extent, they are social buffer rather than productive units. But during periods of stagnating salaries, declines in employment, and insufficient state pensions, semi-subsistence farms can mitigate rural poverty, increase budgets of commercial households and reinforce food security. Since family farming is a dominant agribusiness model in the EU, the Common Agricultural Policy (CAP) addresses supporting family farms (Hennessy, 2014). CAP instruments of Pillars I and II encourage generational turnover in order to attract new entrants and to incentivize investment in fixed assets to improve nature protection, animal welfare, working conditions and products' quality, underpin direct (per hectare) payments for restoring ecosystems, and to promote the transition to a low-carbon economy and resource-efficient technologies. Overall, this suggests the EU commitment to maintaining stable dynamics, balanced prospects, and sustainable development of family farming. Similar research and practical implementations in fostering family farms could be tailored to Ukrainian realities.

Given this context, the goal of this research is to analyze the current state and consider the future prospects of family farming in Ukraine in light of the national and EU experiences. As such, the study tasks were as follows:

1. to study trends in dynamics, stability, and balance of producing typical crop and animal products in commercial households;

2. to identify and compare key economic and social indicators of development relevant to the EU and Ukrainian family farms; and

3. to evaluate profitability and productivity of Ukrainian commercial households with regard to the national agricultural enterprises and private farms to find out strong and weak spheres of the national family farming.

\section{METHODS}

To fulfill the first research task we selected the main kinds of products typical of Ukrainian commercial households, including:

- wheat, maize, sunflower, vegetables, potato, fruit and berries in crop farming;

- beef, pork, broilers, milk, eggs, and honey in animal farming.

A methodical background to depicting production dynamics and industry balance in Ukrainian family farms was econometrics (Greene, 2007; Studenmund, 2016). The examined development of the commercial farming households is described by means of a simple pair regression:

$$
Y=A_{0}+A_{1} \cdot T \text {. }
$$

Here $Y$ consistently denotes

- absolute and relative output dynamics concerning the named 6 crop products;

- absolute and relative output dynamics concerning the listed 6 animal products; 
- total crop and animal productions in commercial households as well as their shares in total Ukrainian crop and animal husbandry.

A variable $T$ designates time. The regression coefficients are $A_{0}$ and $A_{1}$. The latter defines a value of the periodical (in our cases annual) trend in the chosen indicators of $\mathrm{Y}$.

$\mathrm{R}$-squared $\left(\mathrm{R}^{2}\right)$ characterizes the indicators' changes explained by their trends:

$$
R^{2}=\left(\sum_{i=1 \ldots N}\left(T_{i}-\bar{T}\right) \cdot\left(Y_{i}-\bar{Y}\right)\right)^{2} /\left(\sum_{i=1 \ldots N}\left(T_{i}-\bar{T}\right)^{2} \cdot \sum_{i=1 \ldots N}\left(Y_{i}-\bar{Y}\right)^{2}\right),
$$

where

$-\mathrm{N}$ is a population size or number of observations;

$-\overline{\mathrm{T}}$ and $\overline{\mathrm{Y}}$ are the average values of the time $\mathrm{T}$ and the indicator $\mathrm{Y}$.

F-test by Fisher is utilized to confirm the created regression (1) to be significant at a level of $\alpha$ subject to

$$
F(\alpha, N-2)=R^{2} \cdot(N-2) /\left(1-R^{2}\right) .
$$

Stability or volatility in production dynamics and industry balance of Ukrainian family farming is exhibited by a mean absolute deviation

$$
M A D=\sum_{i=I B \ldots I T}\left|Y_{i}-\left(A_{0}+A_{1} \cdot T_{i}\right)\right| /\left(T_{I T}-T_{I B}+1\right),
$$

where

- $\mathrm{T}_{\mathrm{IB}}$ and $\mathrm{T}_{\mathrm{IT}}$ are bottom and top limits of the covered time period;

- $\mathrm{Y}_{\mathrm{i}}$ is the given value of a considered indicator at the moment $\mathrm{T}_{\mathrm{i}}$;

- $\left(A_{0}+A_{1} \cdot T_{i}\right)$ is the value of a considered indicator calculated with the formula (1).

The theoretical framework for considering the second research task is the ranking method (Parlinska \& Parlinska, 2015). We considered common agricultural characteristics of family farms in the EU and commercial households in Ukraine including:

- proportions between crop and animal husbandry; and

- scales of agricultural production such as shares of utilized lands as well as distributions of livestock units.

In order to determine social aspects of family farming we investigated demographic profiles in the EU and Ukraine covering:

- shares of rural population;

- official age of retirement;

- life expectancy;

- age, gender and educational level of head managers on family farms.

To accomplish the third research task, we used statistical comparison methods to analyze effectiveness of agricultural enterprises like the opposite component to commercial households in Ukrainian agriculture (Samarets \& Nuzhna, 2018). We note that some farms consist of partly family holdings, which place these private farms as a medium form between family farms (households) and nonfamily agricultural enterprises (business partnerships, cooperatives, private and state enterprises). The engagement of hired workers in commercial households was $17.7 \%$ in 2018 . However, the share of hired workers with respect to the total labor force in private farms was $63.5 \%$. To illuminate perspectives of small family farming at the national level, we assessed profitability, average yields and shares of agricultural productions in commercial households, private farms and other agricultural enterprises. This approach 
enabled us to identify the critical issues and the most promising directions of providing food security by the family farms in Ukraine.

\section{DYNAMICS, STABILITY, AND BALANCE OF AGRICULTURAL PRODUCTION IN UKRAINIAN COMMERCIAL HOUSEHOLDS}

\subsection{Results}

The source of initial data for the authors' calculations on the problem in question was State statistics service of Ukraine (2019). In order to synchronize research results with Euro-cash, we retrieved data from the period 2002 to 2018. For providing insight into volatilities or differences over time, we divided our samples into two parts: before and after 2009, which corresponds to the tipping point of the global financial crisis. The obtained numerical outcomes were reported in Tables 1-6. They assembled 28 regressions (1), their R-squared values (2) presented as changes explained by trends, $\alpha$ levels of Fsignificance (3) as well as mean absolute deviations around trends in the relevant periods (4). In view of small population sizes caused by the Euro-cash time frame, we practiced informal graphical examination for checking heteroskedasticity which visualized random relationships between the time variable and regression residuals in all explored cases.

Table 1

Absolute development of crop production in Ukrainian commercial households

\begin{tabular}{|l|c|c|c|c|c|}
\hline Product & $\begin{array}{c}\text { Regression to annual } \\
\text { dynamics, thsd. } \mathrm{t}\end{array}$ & $\begin{array}{c}\text { Change } \\
\text { explained by } \\
\text { trend, } \%\end{array}$ & $\begin{array}{c}\alpha \text { to F- } \\
\text { test }\end{array}$ & $\begin{array}{c}\text { MAD in 2002- } \\
\text { 2009, thsd. } \mathrm{t}\end{array}$ & $\begin{array}{c}\text { MAD in 2010- } \\
\text { 2018, thsd. t }\end{array}$ \\
\hline Wheat & $\mathrm{Y}=2563.7+192.31 \cdot \mathrm{T}$ & 70.56 & 0.000 & $463.77^{*}$ & $436.45^{* *}$ \\
\hline Maize & $\mathrm{Y}=1647.4+185.34 \cdot \mathrm{T}$ & 72.60 & 0.000 & 572.73 & 384.68 \\
\hline Sunflower & $\mathrm{Y}=531.9+79.91 \cdot \mathrm{T}$ & 90.15 & 0.000 & 120.36 & 103.90 \\
\hline Vegetables & $\mathrm{Y}=5639.2+180.49 \cdot \mathrm{T}$ & 76.45 & 0.000 & 310.38 & 488.30 \\
\hline Potato & $\mathrm{Y}=17721.0+281.47 \cdot \mathrm{T}$ & 53.14 & 0.001 & 770.77 & 1236.15 \\
\hline Fruit and berries & $\mathrm{Y}=1090.0+45.24 \cdot \mathrm{T}$ & 70.63 & 0.000 & 157.61 & 80.18 \\
\hline
\end{tabular}

Source: Authors' calculations based on data from State statistics service of Ukraine (2019).* and ** mean in 2004-2010 and in 2011-2018.

Firstly, as of 2019 , national family farms produce $20.8 \%$ of wheat, $14.2 \%$ of maize, $13.9 \%$ of sunflower, $85.6 \%$ of vegetables, $98.1 \%$ of potatoes, and $78.4 \%$ of fruit and berries. To control the spikes in the wheat harvest caused by unfavorable climatic conditions in 2003, we extracted the corresponding data for 2004-2018 in Table 1. In this fashion, Table 1 combines calculations in absolute terms on development of crop production in Ukrainian commercial households. Table 2 aggregates figures on relative dynamics in crop production of commercial farming households compared to shares of outputs of agricultural enterprises. 
Table 2

Relative development of crop production in Ukrainian commercial households

\begin{tabular}{|l|c|c|c|c|c|}
\hline Product & $\begin{array}{c}\text { Regression to annual } \\
\text { dynamics, p.p. }\end{array}$ & $\begin{array}{c}\text { Change } \\
\text { explained by } \\
\text { trend, } \%\end{array}$ & $\begin{array}{c}\alpha \text { to F- } \\
\text { test }\end{array}$ & $\begin{array}{c}\text { MAD in 2002- } \\
\text { 2009, p.p. }\end{array}$ & $\begin{array}{c}\text { MAD in 2010- } \\
2018, p . p .\end{array}$ \\
\hline Wheat & $\mathrm{Y}=17.4+0.26 \cdot \mathrm{T}$ & 42.96 & 0.008 & $1.08^{*}$ & $1.14^{* *}$ \\
\hline Maize & $\mathrm{Y}=40.9-1.84 \cdot \mathrm{T}$ & 74.99 & 0.000 & 4.93 & 4.09 \\
\hline Sunflower & $\mathrm{Y}=20.6-0.42 \cdot \mathrm{T}$ & 55.75 & 0.001 & 2.32 & 0.63 \\
\hline Vegetables & $\mathrm{Y}=88.8-0.20 \cdot \mathrm{T}$ & 41.61 & 0.005 & 0.99 & 0.77 \\
\hline Potato & $\mathrm{Y}=98.5-0.08 \cdot \mathrm{T}$ & 29.57 & 0.024 & 0.33 & 1.32 \\
\hline Fruit and berries & $\mathrm{Y}=88.5-0.48 \cdot \mathrm{T}$ & 68.27 & 0.000 & 1.54 & 0.67 \\
\hline
\end{tabular}

Source: Authors' calculations based on data from State statistics service of Ukraine (2019). * and ** mean in 2004-2010 and in 2011-2018.

Secondly, so far the national family farms produce $75.6 \%$ of beef, $48.8 \%$ of pork, $13.8 \%$ of broilers, $72.6 \%$ of milk, $44.8 \%$ of eggs, and $98.8 \%$ of honey. Table 3 presents results of calculations in absolute figures on development of animal production in Ukrainian commercial farming households. Table 4 contains findings on their relative dynamics compared to shares of outputs in agricultural enterprises.

Table 3

Absolute development of animal production in Ukrainian commercial households

\begin{tabular}{|c|c|c|c|c|c|}
\hline Product & $\begin{array}{c}\text { Regression to annual dynamics, } \\
\text { thsd. t }\end{array}$ & $\begin{array}{c}\text { Change } \\
\text { explained by } \\
\text { trend, } \%\end{array}$ & $\begin{array}{l}\alpha \text { to } F_{-} \\
\text {test }\end{array}$ & $\begin{array}{l}\text { MAD in 2002- } \\
2009 \text {, thsd. } t\end{array}$ & $\begin{array}{l}\text { MAD in 2010- } \\
2018 \text {, thsd. } t\end{array}$ \\
\hline Beef & $\mathrm{Y}=468.8-13.37 \cdot \mathrm{T}$ & 90.22 & 0.000 & 18.04 & 19.09 \\
\hline Pork & $\mathrm{Y}=457.7-7.50 \cdot \mathrm{T}$ & 51.70 & 0.001 & 42.79 & 13.11 \\
\hline Broilers & $\mathrm{Y}=166.8+1.04 \cdot \mathrm{T}$ & 13.96 & 0.140 & 10.81 & 11.05 \\
\hline Milk & $\mathrm{Y}=11600-253.04 \cdot \mathrm{T}$ & 94.56 & 0.000 & 315.58 & 149.89 \\
\hline Eggs & $\mathrm{Y}=6274.2+59.17 \cdot \mathrm{T}^{*}$ & 81.25 & 0.000 & $82.53^{*}$ & $115.73 *$ \\
\hline Honey & $\mathrm{Y}=60319.0+561.75 \cdot \mathrm{T}^{* *}$ & 14.15 & 0.137 & $7925.22^{* *}$ & $4074.52^{* *}$ \\
\hline
\end{tabular}

Source: Authors' calculations based on data from State statistics service of Ukraine (2019).* and ** mean in mln. pieces and in tons. 
Relative development of animal production in Ukrainian commercial households

\begin{tabular}{|l|c|c|c|c|c|}
\hline Product & $\begin{array}{c}\text { Regression to annual } \\
\text { dynamics, p.p. }\end{array}$ & $\begin{array}{c}\text { Change } \\
\text { explained by } \\
\text { trend, } \%\end{array}$ & $\begin{array}{c}\alpha \text { to F- } \\
\text { test }\end{array}$ & $\begin{array}{c}\text { MAD in 2002- } \\
\text { 2009, p.p. }\end{array}$ & $\begin{array}{c}\text { MAD in 2010- } \\
\text { 2018, p.p. }\end{array}$ \\
\hline Beef & $\mathrm{Y}=69.2+0.43 \cdot \mathrm{T}$ & 58.76 & 0.000 & 1.72 & 1.44 \\
\hline Pork & $\mathrm{Y}=83.6-2.44 \cdot \mathrm{T}$ & 92.79 & 0.000 & 3.10 & 2.74 \\
\hline Broilers & $\mathrm{Y}=45.9-2.30 \cdot \mathrm{T}$ & 74.54 & 0.000 & 7.00 & 3.42 \\
\hline Milk & $\mathrm{Y}=82.6-0.48 \cdot \mathrm{T}$ & 52.94 & 0.001 & 2.16 & 1.25 \\
\hline Eggs & $\mathrm{Y}=52.0-0.80 \cdot \mathrm{T}$ & 40.09 & 0.006 & 3.23 & 5.44 \\
\hline Honey & $\mathrm{Y}=96.0+0.18 \cdot \mathrm{T}$ & 93.68 & 0.000 & 0.27 & 0.13 \\
\hline
\end{tabular}

Source: Authors' calculations based on data from State statistics service of Ukraine (2019).

As of 2019 the output of the national family farms consisted of $66.6 \%$ and $33.4 \%$ of crop and animal products. Tables 5 and 6 show computed results concerning the total development and balance between crop and animal industries in Ukrainian commercial households.

Table 5

Development of family farming in Ukraine

\begin{tabular}{|l|c|c|c|c|c|}
\hline Industry & $\begin{array}{c}\text { Regression to annual } \\
\text { dynamics, } € \text { mln. }\end{array}$ & $\begin{array}{c}\text { Change } \\
\text { explained } \\
\text { by trend, } \\
\%\end{array}$ & $\begin{array}{c}\alpha \text { to F- } \\
\text { test }\end{array}$ & $\begin{array}{c}\text { MAD in 2002- } \\
\text { 2009, } € \text { mln. }\end{array}$ & $\begin{array}{c}\text { MAD in 2010- } \\
\text { 2018, } € \text { mln. }\end{array}$ \\
\hline Crop husbandry & $\mathrm{Y}=404.7+127.68 \cdot \mathrm{T}$ & 86.53 & 0.000 & 159.28 & 250.28 \\
\hline Animal husbandry & $\mathrm{Y}=533.2+49.89 \cdot \mathrm{T}$ & 65.90 & 0.000 & 108.76 & 182.10 \\
\hline
\end{tabular}

Source: Authors' calculations based on data from State statistics service of Ukraine (2019).

Table 6

Balance of family farming in Ukraine

\begin{tabular}{|l|c|c|c|c|c|}
\hline Industry & $\begin{array}{c}\text { Regression to annual } \\
\text { dynamics, p.p. }\end{array}$ & $\begin{array}{c}\text { Change } \\
\text { explained } \\
\text { by trend, } \\
\%\end{array}$ & $\begin{array}{c}\alpha \text { to F- } \\
\text { test }\end{array}$ & $\begin{array}{c}\text { MAD in 2002- } \\
\text { 2009, p.p. }\end{array}$ & $\begin{array}{c}\text { MAD in 2010- } \\
\text { 2018, p.p. }\end{array}$ \\
\hline Crop husbandry & $\mathrm{Y}=51.8+0.88 \cdot \mathrm{T}$ & 89.89 & 0.000 & 1.17 & 0.89 \\
\hline Animal husbandry & $\mathrm{Y}=48.2-0.88 \cdot \mathrm{T}$ & 89.89 & 0.000 & 1.17 & 0.89 \\
\hline
\end{tabular}

Source: Authors' calculations based on data from State statistics service of Ukraine (2019).

\subsection{Discussion}

Within the framework of discussion the findings depicted in Table 1 reveal positive annual trend dynamics, indicating a gradual progress in the production of all considered crops. Additionally, potato, 
wheat, and maize harvests had the largest increments by 281.47, 192.31, and 185.34 thousand tons. According to the indicators of output changes, annual trend tendencies are strongest for sunflower and vegetables. The mean absolute deviations around trend revealed the production of sunflower, fruit and berries to be the most stable. The largest volatilities were detected in potato production. Comparing the mean absolute deviation around trend over 2010 to 2018 with that over 2002 to 2009, we find that the harvest of maize became more stable by 188.05 thousand tons. In contrast, vegetable production increased its volatility by 177.92 thousand tons.

Table 2 shows that despite absolute growth in the production of crops (as shown in Table 1), the relative contributions of commercial households declined annually for all crops except wheat. The relative value of wheat output grew by 0.26 percentage point per annum, which implies a higher velocity of production improvements in commercial households rather than in agricultural enterprises. The mean absolute deviations around trend confirm prevailing positions of Ukrainian commercial households in vegetables and potato productions. A decreased volatility in sunflower production means a further dominance of agricultural enterprises in growing this crop. At the same time, a high volatility of over four percentage point in maize production suggests commercial households to remain active growers of this crop.

Table 3 reports progress in the production of broilers, eggs and honey, but negative trends in the production of beef, pork and milk. In contrast, the mean absolute deviations around trend from the earlier to the later period fell by $43 \%$ and $52 \%$ for honey and milk, while output volatility in pork production decreased more than threefold over time. The most stable condition occurs in broiler production.

As it is seen from Table 4, despite a growth in the production of broilers and eggs, relative contributions of commercial households fell by 2.3 and 0.8 percentage point per annum. We note that honey producers enhanced their effect over time. However, a positive relative annual trend dynamics in beef production accompanied a decline in agricultural enterprises, which can be a warning sign for the long-term viability of Ukrainian beef production. Furthermore, the mean absolute deviations around trend reflect consequent stabilization in animal production except for eggs. Nevertheless, the latter one of 5.44 percentage point determines the commercial households to remain valuable complementary contributors to Ukrainian eggs production.

Describing the balance in industrial development of Ukrainian family farms, Table 5 reveals beneficial development by $€ 127.68 \mathrm{mln}$. and $€ 49.89 \mathrm{mln}$. in both crop and animal husbandry. This trend is more significant for crop rather than for animal production. In both cases the mean absolute deviations increased by $57.1 \%$ and $67.43 \%$ after 2009 . In other words, currently agricultural production in commercial farming households shows a positive but unstable achievement.

Table 6 displayed an increasing imbalance in favor of crop husbandry, while animal production in commercial households loses 0.88 percentage point per annum. High indications of change explained by the trend and respective declines in mean absolute deviations suggest that such tendency is significant and stable.

\section{ECONOMIC AND SOCIAL COMPARISON BETWEEN UKRAINIAN AND EU FAMILY FARMING}

\subsection{Results}

We now analyze economic characteristics of Ukrainian commercial households in the context of EU family farms. Firstly, agricultural production in the EU is more balanced, so that the proportion between crop and animal husbandry is $55.3 \%$ and $44.7 \%$., respectively. EU countries with the lowest development 
of animal production are Bulgaria (26.2\%), Romania (25.8\%), and Greece (24.6\%); thus, animal production in Ukraine is more balanced than in these countries.

Secondly, the share of utilized agricultural areas in Ukrainian commercial farming households is $30.5 \%$, in contrast to family farming in the EU, which utilizes $66.3 \%$ of agricultural lands. An average size of family farm in the EU is $9.3 \mathrm{ha}$. By comparison, $2 \%$ of family farms in Ukraine with agricultural areas over 10 ha encompass $29.7 \%$ of the utilized lands cultivated by commercial households (State statistics service of Ukraine, 2019).

Thirdly, $66.8 \%$ of the national commercial households in Ukraine take part in animal production. In particular, $32 \%$ of family farms are involved in milk production, $40 \%$ of commercial households raise pigs, $96 \%$ of family farms produce eggs and broilers. Overall, the national commercial households retain $56.3 \%$ of all livestock units in Ukrainian agriculture. By comparison, this indicator in the EU is about $70 \%$. However, Ukrainian commercial households are on average small animal producers, keeping 14 poultry per family farm. Just 1 out of 6 households raises 3 or more pigs, and 1 out of 4 family farms keeps 2 or more cows (State statistics service of Ukraine, 2019). In contrast, about $85 \%$ of livestock units in the EU are distributed among large family farms with revenues over $€ 25,000$.

Social aspects of family farming in any country are correlated with a demographic profile. Thus, rural development is connected with the share of rural population. Presently, this indicator in Ukraine amounts to $30.8 \%$, which is slightly less than $32.8 \%$ from 20 years ago. Considering basic family characteristics, it should be noted that current rates of registered marriages and divorces remained stable around 6.5 and 3.3 per 1000 of present Ukrainian population. At the same time, the distribution of Ukrainian population by age groups shifted from $18.1 \%$ to $16.3 \%$ for those below 16 years of age, remained relatively unchanged at about $60.5 \%$ for adults aged between 16 and 60 , and rose from $21.4 \%$ to $23.2 \%$ for seniors over 60 years of age (State statistics service of Ukraine, 2019). These facts contribute to a reduction in generational turnover in Ukrainian family farming. Nevertheless, it is not a unique issue. The current share of rural population in the EU ranges from 4\% (in Belgium and Malta) up to 50\% in Slovenia. The Ukrainian indicator can be ranked 18th, placing it between Latvia (30\%) and Lithuania (31\%). Average age in the EU varies between 37 in Cyprus and 48 in Italy. By comparison, this indicator in Ukraine accounts for 41 and can be ranked 4th with Sweden, the United Kingdom, and Slovakia (World Bank Open Data, 2019).

The increased life expectancy and higher official age of retirement signal the importance of maintaining a labor force in the EU family farming. Indeed, female life expectancy varies from 78 in Bulgaria to 85.5 in Spain. Male life expectancy ranges between 68.1 in Lithuania and 80.7 in Sweden. Official age of retirement varies from 60 in Austria and Poland to 67 in Greece for women; for men it ranges between 62 (in France and Slovakia) and 67 (in Italy and Greece). In contrast, the age of retirement in Ukraine is currently 60 for men and 58 for women. Unfortunately, such figures are likely affected by relatively low life expectancy of 76.1 for women and 66.3 for men (State statistics service of Ukraine, 2019).

\subsection{Discussion}

Under the angle of summarizing economic parallels between Ukrainian commercial households and the EU family farms, it is notable that proportion of production in Ukrainian family farming is close to the ratio of $60-64 \%$ to $40-36 \%$, as found in Portugal, France, Croatia, Spain, Hungary, Lithuania, and Italy (Cook, 2018). Ukrainian indicators are ranked 4th, between Bulgaria and Estonia, where family farms utilize $25.9 \%$ and $41.3 \%$ of agricultural area (Agriculture statistics - family farming in the EU, 2019). The average total size of land shares and rented plots per commercial farming household in Ukraine equals to 2.97 ha. Small average utilized areas under 10 ha are typical in 11 EU countries: Bulgaria, Croatia, Cyprus, 
Greece, Hungary, Italy, Malta, Poland, Portugal, Romania, and Slovenia. Large average land areas between 10 and 30 ha are found in 8 EU countries: Austria, the Czech Republic, Estonia, Latvia, Lithuania, the Netherlands, Slovakia, and Spain. Ukrainian scale in animal farming is ranked 9th between Spain and both Denmark and Latvia, where family farms keep 52\% and 57\% (twice) of all livestock units (Agriculture statistics - family farming in the EU, 2019). Like in Ukraine, small and medium-sized family farms in Bulgaria, Croatia, Lithuania, Slovenia, and Romania keep at least $35 \%$ of livestock units (Forti \& Henrard, 2016).

The analyzed demographic tendencies entail social profile of head managers on family farms. In particular, the share of family farms' managers over 55 years old accounts for approximately $35 \%$ in the EU. Their weight is above $60 \%$ in Bulgaria, Cyprus, Italy, Portugal, Romania, Spain, and the United Kingdom. However, age of households' heads in Ukraine is on average around 60. Like in other economic sectors, gender proportion in managing family farms shifts in favor of men (Doss et al., 2018). The average share of the female farm managers in the $\mathrm{EU}$ is $28.5 \%$ ranging between $6 \%$ in Malta and $7.7 \%$ in Denmark up to $44.9 \%$ in Latvia and Lithuania (Cook, 2018). The statistical yearbook of "Main agricultural characteristics of households in rural area" (State statistics service of Ukraine, 2019) gave evidence that gender ratio is better balanced in Ukrainian households where a share of female managers amounts to $52.7 \%$. However, male managers $(55 \%)$ prevail over female ones $(45 \%)$ in households with the utilized land over 1.0 ha (State statistics service of Ukraine, 2019).

\section{DOMESTIC COMPETITIVENESS OF UKRAINIAN COMMERCIAL HOUSEHOLDS}

\subsection{Results}

To improve prospects of family farms among the domestic rivals, we consider the effectiveness of Ukrainian commercial farming households and other agricultural enterprises. The latter ones incorporate partly family private farms and other non-family holdings. For the period of 2016-2018, the number of private farms in Ukraine declined to 33,164 holdings, which represents a decrease from $70.6 \%$ to $67.4 \%$ of all agricultural enterprises. In contrast, the number of non-family agricultural enterprises increased to 16,044 , or changed from $29.4 \%$ to $32.6 \%$ of all agricultural enterprises. Consequently, relative outputs of private farms remained relatively small. In particular, private farms encompassed 13.7\%, 19.5\%, 2.9\%, $0.5 \%, 4.6 \%, 2.5 \%, 2.8 \%, 2.3 \%, 1.9 \%, 0.6 \%$ and $0.2 \%$ in producing grain crops, sunflower, vegetables, potato, fruit and berries, beef, pork, broilers, milk, eggs and honey. Similar shares of other agricultural enterprises amounted to $65.0 \%, 66.8 \%, 11.4 \%, 1.5 \%, 14.2 \%, 23.3 \%, 49.5 \%, 84.4 \%, 24.9 \%, 53.5 \%$ and $1.1 \%$ on average for 2016-2018. To a certain extent, the higher profitability of vegetables (16.1\%), potato $(23.3 \%)$, fruit and berries (35.4\%), milk (22.4\%), and eggs (11.7\%) in private farms explain their existence and competitiveness compared to other non-family agribusinesses, where the corresponding indicators were only $12.8 \%, 5.8 \%, 22.3 \%, 20.5 \%$, and $-1.0 \%$ (State statistics service of Ukraine, 2019).

Agricultural enterprises are associated with medium and large agribusiness, while Ukrainian family farms can be considered smallholder farmers. Moreover, $76.7 \%$ of utilized lands belong to agricultural enterprises that have over 1000 ha of agricultural areas. Half of agricultural enterprises involved in milk production have over 100 heads of cows. Furthermore, 66\% of all agricultural enterprises raised 200 and more heads of pigs. Finally, $58.4 \%$ of all agricultural enterprises kept over 5000 heads of poultry per an entity (State statistics service of Ukraine, 2019). Due to large scales of production and high quality standards, agricultural enterprises are the most prevalent of Ukrainian exporters to global food security system. Meanwhile, Ukrainian family farms or commercial households are more capable of saturating the domestic market with qualitative affordable food (Vasylieva, 2019). However, their effectiveness needs 
considerable improvements. In particular, the national commercial households harvested only $3.8 \mathrm{t} / \mathrm{ha}$ of wheat, $4.5 \mathrm{t} / \mathrm{ha}$ of maize, $1.7 \mathrm{t} / \mathrm{ha}$ of sunflower, $19.5 \mathrm{t} / \mathrm{ha}$ of vegetables, and $16.7 \mathrm{t} / \mathrm{ha}$ of potato on average for 2016 to 2018 . At the same time, agricultural enterprises gathered $4.2 \mathrm{t} / \mathrm{ha}$ of wheat, $7.3 \mathrm{t} / \mathrm{ha}$ of maize, $2.3 \mathrm{t} / \mathrm{ha}$ of sunflower, $41.5 \mathrm{t} / \mathrm{ha}$ of vegetables, and $23.4 \mathrm{t} / \mathrm{ha}$ of potato. Their live weight per head of cattle for slaughter was $369.3 \mathrm{~kg}$ and the annual milk yield reached 6.0 tons per cow. Similar indicators in Ukrainian commercial households were $262.3 \mathrm{~kg}$ and 4.5 tons respectively (State statistics service of Ukraine, 2019).

\subsection{Discussion}

In discussion of the prospects for enhancing competitiveness of Ukrainian family farm, our proposed options on ameliorating the marked pressing issue are as follows.

First, low yields in commercial farming households are linked with outdated management practices, compared to the practices applied in Ukrainian agricultural enterprises (Vasylieva \& Velychko, 2017). This can be improved since the educational level of farm heads in Ukraine surpasses the average EU share of $9 \%$ of farm managers with full agricultural training. By comparison, in other EU counties, including Croatia, Cyprus, Greece, Hungary, Malta, Portugal, Romania, and Spain, the share of highly educated farm heads is below $5 \%$. However, the number of farm managers with full agricultural training exceeds $30 \%$ in the Czech Republic, France, Latvia, and Luxemburg (Cook, 2018).

Second, low yields in Ukrainian family farms are largely caused by poor financing and inadequate machinery (Khalatur et al., 2018; Velychko \& Velychko, 2019), which can have negative impacts on basic principles and practices of effective husbandry. Similarly, only $61.5 \%$ and $26.6 \%$ of commercial households can afford mineral fertilizers and regional adapted crop varieties. About $17 \%$ of the national family farms do not apply organic manure and plant protection chemicals. Households are able to afford $31.2 \%, 20.9 \%$, and $35 \%$ of concentrated, coarse and rich fodders compared to $73.5 \%, 8.9 \%$, and $14.8 \%$ of the same fodders in Ukrainian agricultural enterprises. Additionally, just $47.5 \%$ and $57.2 \%$ of family farms stand veterinary checks and sanitary treatment of stock-breeding buildings. Only $17.9 \%$ of households handle sanitary control of milk quality (State statistics service of Ukraine, 2019).

Third, low effectiveness of Ukrainian commercial households is associated with small utilized areas, which can be traced to the prolonged ban for land trade in Ukraine (Skrypnyk et al., 2018). Indeed, not all of family farms in the EU are small. More than $75 \%$ of cereals, oilseed, and protein crops, outdoor and indoor horticulture, grazing livestock are concentrated in large family farms with revenues over $€ 25,000$ (Forti \& Henrard, 2016). Fortunately, there is positive progress on the issue in question. On 1 July, 2021, a new Ukrainian market law should enter into force (Law of Ukraine, 2020). Between 2021 and 2023, only individuals, not entities, would be able to become owners of up to 100 ha of agricultural land. After the indicated period the maximum size of agricultural land in the possession of a Ukrainian citizen would increase to 10,000 ha.

\section{CONCLUSION}

Family farms in Ukraine are represented by commercial households that focus their economic activity on food self-sufficiency and commodity agricultural production. This activity maintains incomes for more than 13 million people in rural regions in Ukraine and provides food security at the national level through the production of vegetables, potato, fruit and berries, milk, beef, honey, as well as half of pork and eggs. Despite upward production trends in many agricultural commodities, annual outputs are unstable and unbalanced, with an increasing trend in favor of crop production. 
While Ukrainian commercial households generally produce more than partly family private farms, they lag behind the agricultural enterprises in terms of yields and applications of advanced agricultural technologies. Nevertheless, calculated management and diversified farming would bring the expected advantages. Even under the current restrictions, diversification in Ukraine may provide appropriate revenue of more than $€ 8,000$ in term of the EU medium-sized farms. Such options are as follows:

- keeping 90 hens laying 280 pieces per annum priced for $€ 0.8$ per 10 eggs and 3 cows with annual yield of 5.7 tons priced for $€ 35$ per $100 \mathrm{~kg}$ of milk;

- growing 0.5 ha of cabbage, onions, and carrot with their yields of $24 \mathrm{t} / \mathrm{ha}, 16 \mathrm{t} / \mathrm{ha}$, and $19 \mathrm{t} / \mathrm{ha}$ priced for $€ 0.3$, €0.4, and $€ 0.2$ per $\mathrm{kg}$;

- growing $0.75 \mathrm{ha}, 0.25 \mathrm{ha}$, and 0.5 ha of apples, strawberry, and walnuts with their yields of $12 \mathrm{t} / \mathrm{ha}$, $7 \mathrm{t} / \mathrm{ha}$, and $8 \mathrm{t} / \mathrm{ha}$ priced for $€ 0.25, € 1.1$, and $€ 1$ (unshelled) per $\mathrm{kg}$;

- growing 4 ha, 4 ha, and 3 ha of wheat, maize, and sunflower with their yields of 4.1 t/ha, 6.2 t/ha, and $2 \mathrm{t} /$ ha priced for $€ 165, € 140$, and $€ 330$ per ton.

Overall, family farming is a prevalent model in EU agriculture. In light of Ukrainian adherence to European integration and the existence of common features of agriculture in Ukraine and Europe, the knowledge, experience and practices of family farming in the EU should be delivered to Ukrainian commercial households. To be sure, the EU pattern is an important model for avoiding further decreases in Ukrainian animal husbandry, attracting young generation to family farming, amplifying the national food security, eliminating poverty, and providing prosperity in Ukrainian rural territories.

\section{Acknowledgement}

This research received no specific grant from any funding agency in the public, commercial, or not-for-profit sectors.

\section{REFERENCES}

Agriculture statistics - family farming in the EU (2019). Eurostat: Statistics Explained. Retrived from https://ec.europa.eu/eurostat/statistics-explained/index.php/Agriculture_statistics_-_family_farming_in_ the_EU (19.01.2020).

Babenko, V., Pasmor, M., Pankova, J., \& Sidorov, M. (2017). The place and perspectives of Ukraine in international integration space. Problems and Perspectives in Management, 15(1), 80-92. doi: 10.21511/ppm.15(1).2017.08.

Bosc, P.-M., Sourisseau, J.-M., Bonnal, P., Gasselin, P., Valette, E. \& Bélières, J.-F. (Ed.) (2018). Diversity of Family Farming Around the World: Existence, Transformations and Possible Futures of Family Farms. Berlin: Springer.

Cook, E. (Ed.) (2018). Agriculture, forestry and fishery statistics. Luxembourg: Publications Office of the European Union. Retrived from: https://ec.europa.eu/eurostat/ publications/statistical-books (18.01.2020).

Davidova, S., Bailey, A., Dwyer, J., Erjavec, E., Gorton, M., \& Thomson, K. (2013). Semi-Subsistence Farming - Value and Directions of Development: Study. Brussels: Directorate General for Internal Policies Policy, Department B: Structural and Cohesion Policies, Agriculture and Rural Development, The European Parliament. Retrived from: https://www.europarl.europa.eu/RegData/etudes/etudes/join/2013/495861/IPOL-AGRI_ ET(2013) 495861_EN.pdf (19.01.2020).

Davidova, S., \& Thompson, K. (2014). Family Farming in Europe: Challenges and Prospects: In-Depth Analysis. Brussels: Directorate General for Internal Policies Policy, Department B: Structural and Cohesion Policies, Agriculture and Rural Development, The European Parliament. Retrived from: http://www.europarl.europa.eu/ RegData/etudes/note/join/2014/529047/IPOL-AGRI_NT(2014)529047_EN.pdf (18.01.2020).

Doss, C., Meinzen-Dick, R., Quisumbing, A., \& Theis, S. (2018). Women in agriculture: Four myths. Global Food Security, 16, 69-74. doi: 10.1016/ j.gfs.2017.10.001.

Family Farming Knowledge Platform (2019). Food and Agriculture Organization of the United Nations: Countries \& Regions. Retrived from: http://www.fao. org/family-farming/countries/en/ (18.01.2020). 
Fienitz, M. (2017). Small Farms in Europe: Viable but Underestimated. Cluj-Napoca: Eco Ruralis, The Access to Land Network. Retrived from: https://www.accesstoland.eu/IMG/pdf/small_farms_in_europe_-_viable_but_ underestimated.pdf (19.01.2020).

Forti, R., \& Henrard, M. (Ed.). (2016). Agriculture, forestry and fishery statistics. Luxembourg: Publications Office of the European Union. Retrived from: https:/ / ec.europa.eu/eurostat/publications/statistical-books (19.01.2020).

Gardner, B. (2013). Global Food Futures: Feeding the World in 2050. London: Bloomsbury Academic.

Grafton, R. Q., Daugbjerg, C., \& Qureshi, M. E. (2015). Towards food security by 2050. Food Security, 7(2), 179-183. doi: 10.1007/s12571-015-0445-x.

Greene, W. H. (2007). Econometric analysis. Upper Saddle River, New Jersey: Pearson Prentice Hall.

Hennessy, T. (2014). CAP 2014-2020 Tools to Enhance Family Farming: Opportunities and Limits:In-Depth Analysis. Brussels: Directorate General for Internal Policies Policy, Department B: Structural and Cohesion Policies, Agriculture and Rural Development. The European Parliament. Retrived from: http://www.europarl. europa.eu/RegData/ etudes/note/join/2014/529051/IPOL-AGRI_NT(2014)529051_EN.pdf (19.01.2020).

Khalatur, S., Zhylenko, K., Masiuk, Yu., Velychko, L., \& Kravchenko, M. (2018). Assessment of bank lending diversification in Ukraine. Banks and Bank Systems, 13(3), 141-150. doi: 10.21511/bbs.13(3).2018.14.

Knorr, D., Kho, C. S. H., \& Augustin, M. A. (2018). Food for an Urban Planet: Challenges and Research Opportunities. Frontiers in Nutrition, 4(73). doi: 10.3389/fnut.2017. 00073.

Law of Ukraine (2020). On changing some legislative acts of Ukraine concerning conditions of agricultural land turnover. The Law of Ukraine \# 552-IX passed on 3 March, 2020. Retrived from: https://zakon.rada.gov.ua/laws/show/55220\#Text (15.07.2020).

Lowder, S.K., Skoet, J., \& Raney, R. (2016). The Number, Size, and Distribution of Farms, Smallholder Farms, and Family Farms Worldwide. World Development, 87(11), 16-29. doi: 10.1016/j.worlddev.2015.10.041.

McKenzie, F. C., \& Williams, J. (2015). Sustainable food production: constraints, challenges and choices by 2050. Food Security, 7(2), 221-233. doi: 10.1007/s12571-015-0441-1.

Parlinska, M., \& Parlinska, A. (2015, April). Characteristic of Family Farming in the European Union. Proceedings of the International Conference "Economic Science for Rural Development", Jelgava, LLU ESAF, 38, 113-119. Retrived from: http://llufb.llu.lv/conference/economic_science_rural/2015/Latvia_ESRD_38_2015-113119 (18.01.2020).

Rapsomanikis, G. (2015). The Economic Lives of Smallholder Farmers. Rome: Food and Agriculture Organization of the United Nations. Retrived from: http://www.fao.org/3/a-i5251e.pdf (18.01.2020).

Ricciardi, V., Ramankutty, N., Mehrabi, Z., Jarvis, L., \& Chookolingo, B. (2018). How much of the world's food do smallholders produce? Global Food Security, 17, 64-72. doi: 10.1016/j.gfs.2018.05.002.

Samarets, N., \& Nuzhna, S. (2018). The modern contribution of the basic categories of producers to Ukrainian agrarian production. Agricultural and Resource Economics: International Scientific E-Journal, 4(4), 52-71. Retrived from: http://are-journal.com (19.01.2020).

Skrypnyk, A., Tkachuk, V., Andruschenko, V., \& Bukin, E. (2018). Sustainable development facets: farmland and market demand estimation. Journal of Security and Sustainability Issues, 7(3), 513-525. doi: 10.9770/jssi.2018.7.3(11).

Sourisseau, J.-M. (Ed.) (2015). Family Farming and the Worlds to Come. Berlin: Springer.

State Statistics Service of Ukraine (2019). Agriculture in Ukraine: Statistics. Retrived from: http://www.ukrstat.gov.ua/ (19.01.2020).

Studenmund, A..H. (2016). Using Econometrics: A Practical Guide. London: Pearson plc.

Valin, H., Sands, R. D., van der Mensbrugghe, D. et al. (2014). The Future of Food Demand: Understanding Differences in Global Economic Models. Agricultural Economics, 45(1), 51-67. doi: 10.1111/agec.12089.

Vasylieva, N., \& Velychko, O. (2017). Development of the controlling system in the management of dairy clusters. Eastern European Journal of Enterprise Technologies, 4(3(88)), 20-26. doi: 10.15587/1729-4061.2017.108591.

Vasylieva, N. (2019). Problems and Prospects of Food Security in Ukraine. Bulgarian Journal of Agricultural Science, 25(4), 668-676. Retrived from: http://www.agrojournal.org/25/04-08.pdf (18.01.2020). 
Velychko, O., \& Velychko, L. (2017). Management of inter-farm use of agricultural machinery based of the logistical system «BOA». Bulgarian Journal of Agricultural Science, 23(4), 534-543. Retrived from: http:/ /www.agrojournal.org/23/04-03.pdf (19.01.2020).

World Bank Open Data (2019). Countries in the world by population: Statistics. Retrived from: https://data.worldbank.org/ (18.01.2020). 